\title{
INFLUENCE ANALYSIS EXPENSE OF PROMOTION, GENERAL EXPENSE AND VOLUME OF TRADING TO PROFIT AT SAMIDI GLASS \& CRAFT GONDANG, BALANCE, SUKOHARJO
}

\author{
Oleh \\ Jumingan \\ Dosen STIE Surakarta \\ Sarwanti \\ Dosen STIE Surakarta
}

\begin{abstract}
Promotion is processing satisfaction giving to consumer to get profit. Sensible promotion become determinant success of every small or big company, orientation which profit or nirlaba, domestic and or global. Company management must can plan correctly and can estimate in in all change influence of expense of promotion, general expense, volume of trading and selling price to profit. This research internal issue formula is : 1) Are there influence expense of promotion to profit at Samidi Glass \& Craft Gondang, Balance, Sukoharjo ?. 2) Are there general expense influence to profit at Samidi Glass \& Craft Sukoharjo ?. 3) Are there volume of trading influence to profit at Samidi Glass \& Craft Sukoharjo. Purpose of in this research is: 1) To know influence expense of promotion to profit at Samidi Glass \& Craft Sukoharjo. 2) To know general expense influence to profit at Samidi Glass \& Craft Sukoharjo. 3) To know volume of trading influence to profit at Samidi Glass \& Craft Gondang, Balance, Sukoharjo. Hypothesis submitted is: 1) Anticipated there are influence expense of promotion to profit. 2) Anticipated there are general expense influence to profit. 3) Anticipated there are volume of trading influence to profit.

Analyzer applied in this research is Uji Data: Data Normality Test and Uji Linieritas, Hypothesis Test: Parsial Regression Analysis, Regression Analysis Linieritas Berganda, Test Signifikasi: Test $t$, Test F, Uji R2 ( Coefficient of determination).Based on result of analysed hence inferential : 1) There is influence expense of promotion to profit. 2) there is general expense influence to profit. 3) there is volume of trading influence to profit.
\end{abstract}

Keyword : Expense Of Promotion, General expense, Volume of trading and Profit.

\section{PENDAHULUAN}

Semakin ketatnya persaingan didalam dunia usaha pada saat sekarang ini, membuat para pelaku usaha baik itu perseorangan atau persekutuan, ataupun dalam bentuk perusahaan baik itu perusahaan yang berasal dalam atau luar negeri haruslah memiliki faktor yang dapat dijadikan oleh perusahaan sebagai senjata dalam usahanya untuk memenangkan persaingan dengan para pesaingnya didunia bisnis.

Meskipun perusahaan telah berusaha bersaing dan memberikan yang terbaik untuk konsumen belum tentu dapat menjamin akan berhasilnya usaha pencapaian tujuan perusahaan, karena tiap konsumen memiliki selera dan keinginan yang berbeda-beda. Maka dari itu setiap perusahaan memiliki strategi pemasaran yang berbeda-beda, tentunya strategi promosi yang diterapkanlah strategi terbaik disetiap perusahaan.

Influence Analysis Expense Of Promotion, General Expense And Volume Of Trading

To Profit At Samidi Glass \& Craft Gondang, Balance, Sukoharjo

(Jumingan, Sarwanti) 
Dengan melakukan hal tersebut perusahaan dapat menarik minat, ketertarikan, dan menggugah masyarakat untuk membeli produk barang atau jasa yang dihasilkan perusahaan tersebut. Promosi lebih berhubungan dengan pelanggan dibandingkan dengan fungsi bisnis lain. Memahami, menciptakan, mengkomunikasikan, dan memberikan nilai dan kepuasan kepada konsumen adalah inti pemikiran dan praktek promosi. Definisi dari promosi sendiri adalah proses pemberian kepuasan kepada konsumen untuk mendapatkan laba.

Seiring dengan perubahan zaman yang semakin modern dan didukung teknologi canggih, maka kehidupan dunia usaha mengalami persaingan yang ketat. Manajemen perusahaan harus dapat merencanakan dengan tepat dan dapat memperkirakan secara dalam semua pengaruh perubahan biaya promosi, biaya umum, volume penjualan dan harga jual terhadap laba.

Bukti empiris menunjukkan adanya kekonsistenan antara peneliti satu dengan peneliti yang lainnya mengenai pengaruh biaya promosi dan umum terhadap laba dan pengaruh promosi dengan volume penjualan. Penelitian yang dilakukan oleh Kusli (2003), Rida Fitriyani (2001), Tama Karina Florentina Darwanto (2006) menemukan adanya pengaruh yang positif.

Berdasarkan uraian di atas, penelitian ini menganalisis kembali pengaruh biaya promosi, biaya umum dan volume penjualan terhadap laba.

Masalah yang diteliti selanjutnya dapat dirumuskan sebagai berikut: 1) Apakah ada pengaruh biaya promosi terhadap laba?. 2) Apakah ada pengaruh biaya umum terhadap laba?. 3) Apakah ada pengaruh volume penjualan terhadap laba?.

Penelitian ini bertujuan: 1) Untuk mengetahui pengaruh biaya promosi terhadap laba. 2) Untuk mengetahui pengaruh biaya umum terhadap laba. 3) Untuk mengetahui pengaruh volume penjualan terhadap laba.

Hasil dari penelitian ini akan dapat digunakan sebagai bahan masukan dalam menyusun kebijaksanaan dan pengambilan keputusan dalam usahanya meningkatkan volume penjualan dan laba khususnya dalam bidang promosi dan saluran distribusi, dapat mengetahui secara langsung.

\section{TINJAUAN PUSTAKA DAN HIPOTESIS}

1. Akuntansi Biaya

Akuntansi Biaya menurut Mulyadi (1993:6) Akuntansi Biaya adalah proses pencatatan, penggolongan, peringkasan dan penyajian biaya pembuatan dan penjualan produk atau jasa, dengan cara-cara tertentu, serta penafsiran terhadapnya.

Sedangkan menurut R. A. Supriyono (1999:12) Akuntansi Biaya adalah salah satu cabang akuntansi yang merupakan alat manajemen dalam memonitor dan merekam transaksi biaya secara sistematis, serta menyajikan informasi biaya dalam bentuk laporan biaya.

2. Biaya

Menurut R. A. Supriyono (1999:16) Biaya adalah harga perolehan yang dikorbankan atau digunakan dalam rangka memperoleh penghasilan (revenue) dan akan dipakai sebagai pengurang penghasilan.

Sedangkan menurut Mulyadi (1993:8) Biaya dalam arti luas adalah pengorbanan sumber ekonomis yang diukur dalam satuan uang yang telah terjadi atau kemungkinan terjadi untuk mencapai tujuan tertentu. Sedangkan biaya dalam arti sempit adalah pengorbanan sumber ekonomi untuk memperoleh aktiva.

Penggolongan biaya menurut mulyadi (1993:14) terdapat berbagai macam cara 
penggolongan biaya yaitu

a. Penggolongan biaya atas dasar objek pengeluaran (Biaya bahan baku, Biaya tenaga kerja dan biaya overhead pabrik (BOP)).

b. Penggolongan biaya atas dasar fungsi-fungsi pokok dalam perusahaan (Biaya administrasi dan umum, biaya produksi dan biaya promosi).

c. Penggolongan biaya atas dasar hubungan biaya dengan sesuatu yang dibiayai (Biaya langsung dan biaya tak langsung).

d. Penggolongan biaya dengan tingkah lakunya dalam hubungan dengan volume kegiatan biaya (Biaya Tetap, biaya semi variabel dan biaya variabel).

3. Promosi

Menurut Tjiptono (2003:219) promosi adalah suatu bentuk komunikasi pemasaran. Yang dimaksud dengan komunikasi pemasaran adalah aktivitas pemasaran yang berusaha menyebarkan informasi, mempengaruhi / membujuk dan/atau mengingatkan pasar sasaran atas perusahaan dan produknya agar bersedia menerima, membeli dan loyal pada produk yang ditawarkan perusahaan yang bersangkutan.

Menurut Kotler (2004:101) promosi menunjukkan berbagai aktivitas yang dilakukan perusahaan untuk mengkomunikasikan kebaikan produknya dan membujuk para pelanggan dan konsumen untuk membeli produk itu.

Tujuan Promosi adalah menginformasikan, mempengaruhi dan membujuk, serta mengingatkan pelanggan sasaran tentang perusahaan dan bauran pemasarannya.

4. Biaya Promosi

Biaya Promosi adalah biaya yang dikeluarkan oleh perusahaan untuk kegiatan memperkenalkan produk melalui media periklanan.

5. Biaya administrasi dan umum

Biaya administrasi dan umum adalah biaya yang terjadi dan berhubungan dengan fungsi administrasi dan umum.

6. Volume Penjualan

Volume penjualan merupakan hasil produk yang dapat terjual pada periode tertentu. Dengan jumlah volume penjualan tertentu yang dihasilkan akan mendapatkan penghasilan tertentu apabila diselisihkan dengan biaya-biaya produksi akan menghasilkan laba.

7. Laba

Menurut Arsyad (1994:23) laba di definisikan sebagai selisih antara penerimaan dengan biaya. Jika selisih tersebut negatif, disebut rugi atau sebaliknya jika selisih tersebut positif, disebut laba.

\section{HIPOTESIS PENELITIAN}

Berdasarkan uraian dalam bab pendahuluan dan tinjauan pustaka, maka dapat diambil hipotesis penelitian sebagai berikut :

$\mathrm{H}_{1}$ : Diduga ada pengaruh biaya promosi terhadap laba.

$\mathrm{H}_{2}$ : Diduga ada pengaruh biaya umum terhadap laba.

$\mathrm{H}_{3}$ : Diduga ada pengaruh volume penjualan terhadap laba.

Influence Analysis Expense Of Promotion, General Expense And Volume Of Trading 


\section{METODE PENELITIAN}

1. Populasi, Sampel Dan Teknik Pengambilan Sampel

Populasi adalah keseluruhan subyek penelitian (Arikunto, 2002 : 108). Populasi dari penelitian ini adalah Data Biaya dan Laporan Keuangan tahun 2003-2007.

Sampel adalah sebagian atau wakil populasi yang diteliti. Menurut Djarwanto (1998:108). Sampel di dalam penelitian ini adalah data biaya, volume penjualan dan laba tahun 2003-2007.

Teknik pengambilan sampel dalam penelitian ini adalah Purposive Sampling yaitu dilakukan dengan cara mengambil subjek bukan didasarkan atas strata random/daerah tetapi didasarkan atas adanya tujuan tertentu (Suharsimi, Arikunto, 2002:117).

2. Sumber dan Jenis Data

Sumber data dalam penelitian ini adalah data primer (wawancara dengan pemilik dan pegawai perusahaan menganai segala sesuatu yang behubungan dengan penelitian) dan data sekunder (biaya promosi, biaya umum, volume penjualan dan laba tahun 2003-2007)

Sedangkan jenis data dalam penelitian ini adalah data kuantitatif yaitu serangkaian pengukuran yang dapat dinyatakan dengan angka-angka (Soeratno dan lincolin, 1993:76).

3. Teknik Pengumpulan Data

Teknik pengumpulan data dalam penelitian ini adalah Interview/Wawancara, Observasi Studi Kepustakaan

4. Definisi Operasional dan Pengukuran Variabel

a. Biaya Promosi

Biaya Promosi biaya yang dikeluarkan oleh perusahaan untuk kegiatan memperkenalkan produk melalui media periklanan. Biaya promosi dalam penelitian ini diukur dengan rupiah.

b. Biaya Administrasi dan Umum

Biaya administrasi dan umum adalah biaya yang terjadi dan berhubungan dengan fungsi administrasi dan umum. Biaya administrasi dan umum dalam penelitian ini diukur dengan rupiah.

c. Volume Penjualan

Volume penjualan merupakan hasil produk yang dapat terjual pada periode tertentu. Volume penjualan dalam penelitian ini diukur dengan rupiah.

d. Laba

Laba di definisikan sebagai selisih antara penerimaan dengan biaya. Jika selisih tersebut negatif, disebut rugi. Laba dalam penelitian ini diukur dengan menggunakan rumus :

$$
\pi=\mathrm{TR}-\mathrm{TC}
$$

5. Uji Data

a. Uji Normalitas Data

Uji normalitas dimaksudkan untuk mengetahui data residual berdistribusi normal atau tidak. Untuk mendeteksi normalitas model regresi dapat dilakukan pengujian dengan menggunakan grafik normal p-plot yang diolah dengan program SPSS versi 11.00. Jika data menyebar di sekitar garis diagonal dan mengikuti arah garis tersebut berarti modal regresi memenuhi asumsi normalitas. 


\section{b. Uji Linieritas}

Uji linearitas digunakan untuk melihat apakah spesifikasi model yang digunakan sudah benar atau tidak. Dalam penelitian ini pengujian linearitas dilakukan dengan uji Durbin Watson Test. Bila nilai DW Stat lebih besar dari DWU dan lebih kecil dari 4DW (DWU < DW $<4-$ DW). Maka asumsi linearitas terpenuhi.

6. Pengujian Hipotesis

a. Analisis Regresi Parsial

Analisis ini digunakan untuk mengetahui garis regresi yang senyatanya (true regression line) antara variabel independen yang terdiri dari biaya promosi, biaya umum, volume penjualan dan variabel dependen yaitu laba.

Adapun rumus yang digunakan adalah : $\boldsymbol{Y}=\boldsymbol{a}+\boldsymbol{b} \boldsymbol{X}$

Dimana:

$\mathrm{Y}=$ Nilai dependen variabel yang sesungguhnya.

$X=$ Nilai independen variabel

$\mathrm{a}=$ Bilangan konstan, yang merupakan titik potong dengan sumbu vertikal pada gambar kalau nilai $X=0$.

$\mathrm{b}=$ Slope, yaitu koefisien kecondongan garis itu.

b. Analisis Regresi Linier Berganda

analisis ini dapat digunakan untuk mengetahui pengaruh variabel independen (Biaya Promosi $\left(\mathrm{X}_{1}\right)$, Biaya Umum $\left(\mathrm{X}_{2}\right)$, Volume Penjualan (X3)) terhadap variabel dependen (Laba (Y)).

Rumus :

$$
\begin{aligned}
& Y=\boldsymbol{a}+b_{1} \boldsymbol{X}_{1}+\boldsymbol{b}_{2} \boldsymbol{X}_{2}+\boldsymbol{b}_{3} \boldsymbol{X}_{3}+\boldsymbol{e} \text { Dimana: } \\
& \mathrm{Y} \quad: \text { Laba } \\
& \mathrm{a} \quad \text { Konstanta } \\
& \mathrm{b}_{1} \mathrm{~b}_{2} \mathrm{~b}_{3} \quad \text { : Koefisien regresi masing - masing variabel } \\
& \mathrm{X}_{1} \quad \text { : Biaya Promosi } \\
& \mathrm{X}_{2} \quad \text { : Biaya Umum } \\
& \mathrm{X}_{3} \quad \text { : Volume Penjualan } \\
& \mathrm{e} \quad \text { : Error }
\end{aligned}
$$

7. Uji Signifikasi

a. Uji t

Uji t digunakan untuk menunjukkan pengujian variabel-variabel independen secara individu yang dilakukan untuk melihat apakah variabel independen secara individu berpengaruh secara signifikan terhadap variabel dependen, dengan mengasumsikan variabel lainya tetap / konstan.

b. Uji F

Uji F digunakan untuk menunjukkan pengujian variabel-variabel secara keseluruhan dan serentak (yang dilakukan untuk melihat apakah variabel independen secara keseluruhan dan serentak) mempengaruhi variabel dependen secara signifikan.

Influence Analysis Expense Of Promotion, General Expense And Volume Of Trading 


\section{c. Uji Koefisien Determinasi $\mathrm{R}^{2}$}

Uji koefisien determinasi digunakan untuk mengetahui seberapa besar varian dan variabel dependen dapat dijelaskan oleh variabel independen.

\section{HASIL PENELITIAN DAN PEMBAHASAN}

1. Uji Normalitas

Uji normalitas digunakan untuk mengetahui apakah sebuah model regresi mempunyai distribusi normal, dalam hal ini digunakan analisis dengan metode One- Sample Kolmogorov-Smirnov test.

Hasil Pengujian normalitas masing-masing variabel ditunjukkan dalam tabel di bawah ini:

Dari tabel IV.3 dapat diketahui bahwa seluruh variabel berdistribusi normal, sehingga pengujian dapat dilanjutkan.

2. Uji Linearitas

Untuk menganalisis apakah dalam model penelitian yang digunakan ada masalah atau tidak, maka sebagai alat analisisnya dapat digunakan uji Durbin Watson. Berdasarkan perhitungan komputer diperoleh hasil Durbin Watson (DW) sebesar 2,799. Nilai tabel DW untuk $d_{L}(0,05: 5: 1)=1,59$ sedangkan nilai tabel DW untuk $d_{u}(0,05: 5: 1)=1,59$. Karena nilai Durbin Watson lebih besar dari batas atas $\mathrm{d}_{\mathrm{u}}$ maka dapat disimpulkan bahwa data tersebut linier.

3. Analisis Hipotesis

a. Analisis Regresi Parsial

1) Pengaruh Biaya promosi Terhadap Laba

Berdasarkan table Rekapitulasi Regresi Parsial dan Uji t diperoleh nilai koefisien multiple $\mathrm{R}$ adalah 0,978. Karena nilai koefisien multiple $\mathrm{R}>0$ dan mendekati 1 , maka dapat dikatakan bahwa hubungan variabel bebas terhadap variabel tidak bebas adalah positif dan kuat. Untuk perhitungan $\mathrm{R}^{2}$ diperoleh sebesar $0,957=$ $95,7 \%$. Ini berarti variasi variabel laba dipengaruhi variabel bebas (biaya promosi) sebesar $95,7 \%$ dan sisanya 4,3\% dipengaruhi oleh variabel lainnya. Berdasarkan hasil analisis dengan menggunakan alat bantu komputer program SPSS versi 11.00. Diperoleh persamaan regresi parsial, yaitu $: Y=40955295+32,959 X$ Interprestasi dari persamaan tersebut adalah sebagai berikut :

a $\quad=40955295$, jika variabel biaya promosi sama dengan konstan, maka laba meningkat 40955295 rupiah.

$\mathrm{b}_{\text {biaya promosi }}=32,959$, setiap perubahan rata-rata biaya promosi sebesar 1 rupiah akan meningkatkan laba rata-rata sebesar 32,959 rupiah.

2) Pengaruh Biaya Umum Terhadap Laba

Berdasarkan tabel IV.4 Rekapitulasi Regresi Parsial dan Uji t diperoleh diperoleh nilai koefisien multiple $\mathrm{R}$ adalah 0,913. Karena nilai koefisien multiple $\mathrm{R}>0$ dan mendekati 1, maka dapat dikatakan bahwa hubungan variabel bebas terhadap variabel tidak bebas adalah positif dan kuat. Untuk perhitungan $\mathrm{R}^{2}$ diperoleh sebesar $0,833=83,3 \%$. Ini berarti variasi variabel laba dipengaruhi variabel bebas (biaya promosi penjualan) sebesar $83,3 \%$ dan sisanya $16,7 \%$ dipengaruhi oleh variabel lainnya. 
Analisis ini digunakan untuk mengukur besarnya pengaruh antara variabel Biaya Umum $\left(\mathrm{X}_{2}\right)$ dengan Laba $(\mathrm{Y})$.Diperoleh persamaan regresi parsial, yaitu : $\mathrm{Y}=54294134+58,234 \mathrm{X}$ Interprestasi dari persamaan tersebut adalah sebagai berikut :

$$
\begin{gathered}
\mathrm{a}=\quad \begin{array}{l}
54294134, \text { jika variabel Biaya Umum sama dengan konstan, maka } \\
\text { laba meningkat } 29842693 \text { rupiah. }
\end{array} \\
\mathrm{b}_{\text {biaya umum }}=\quad \begin{array}{l}
58,234, \text { setiap perubahan rata-rata biaya umum sebesar } 1 \\
\text { rupiah akan meningkatkan laba rata-rata sebesar 58,234 rupiah. }
\end{array}
\end{gathered}
$$

\section{3) Pengaruh Volume Penjualan Terhadap Laba}

Berdasarkan tabel IV.4 Rekapitulasi Regresi Parsial dan Uji t diperoleh diperoleh nilai koefisien multiple $\mathrm{R}$ adalah 0,925 . Karena nilai koefisien multiple $\mathrm{R}$ $>0$ dan mendekati 1, maka dapat dikatakan bahwa hubungan variabel bebas terhadap variabel tidak bebas adalah positif dan kuat. Untuk perhitungan $\mathrm{R}^{2}$ diperoleh sebesar $0,856=85,6 \%$. Ini berarti variasi variabel laba dipengaruhi variabel bebas (volume penjualan) sebesar $85,6 \%$ dan sisanya $14,4 \%$ dipengaruhi oleh variabel lainnya. Diperoleh persamaan regresi parsial, yaitu : $\mathrm{Y}=$ $338078891,2572+0,898 X$. Interprestasi dari persamaan tersebut adalah sebagai berikut :

$$
\begin{aligned}
& \text { a } \quad=338078891,2572 \text {, jika variabel volume penjualan sama dengan } \\
& \text { konstan, maka laba meningkat 338078891,2572 rupiah. } \\
& \beta_{\text {Volume penjualan }}=0,898 \text {, setiap perubahan rata-rata volume penjualan sebesar } 1 \\
& \text { rupiah akan meningkatkan volume penajualan rata-rata sebesar } \\
& 0,898 \text { rupiah. }
\end{aligned}
$$

b. Analisis Regresi Linier Berganda

Persamaan yang dihasilkan berdasarkan analisis regresi linier berganda adalah sebagai berikut :

$\mathrm{Y}=635267745,503+96,551 \mathrm{X}_{1}+35,714 \mathrm{X}_{2}+1,357 \mathrm{X}_{3}$

Interprestasi dari persamaan tersebut adalah sebagai berikut :

$\mathrm{a}=635267745,503$, jika variabel biaya promosi, biaya umum dan volume penjualan sama dengan konstan, maka laba meningkat 635267745,503 rupiah.

$\mathrm{b}_{1}=96,551$, berarti jika biaya umum $\left(\mathrm{X}_{2}\right)$ dan volume penjualan $\left(\mathrm{X}_{3}\right)$ dianggap tetap, maka dengan adanya kenaikan variabel biaya promosi $\left(\mathrm{X}_{1}\right)$ sebesar Rp. 1,- akan meningkatkan laba sebesar 96,551 rupiah.

$\mathrm{b}_{2}=35,714$, berarti jika biaya promosi $\left(\mathrm{X}_{1}\right)$ dan volume penjualan $\left(\mathrm{X}_{3}\right)$ dianggap tetap, maka dengan adanya kenaikan variabel biaya umum $\left(\mathrm{X}_{2}\right)$ sebesar Rp. 1,akan meningkatkan laba sebesar 35,714 rupiah.

$\mathrm{b}_{3}=1,357$, berarti jika biaya promosi $\left(\mathrm{X}_{1}\right)$ dan biaya umum $\left(\mathrm{X}_{2}\right)$ dianggap tetap, maka dengan adanya kenaikan variabel biaya volume penjualan $\left(\mathrm{X}_{3}\right)$ sebesar $\mathrm{Rp}$. 1,- akan meningkatkan laba sebesar 1,357 rupiah. 


\section{c. Uji T}

Dari perhitungan diperoleh hasil dari $t_{\text {hitung }}$ untuk biaya promosi $\left(\mathrm{X}_{1}\right)$ sebesar 8,207 dan $t_{\text {tabel }}$ sebesar 3,18, berarti $t_{\text {hitung }} \geq t_{\text {tabel }}$ maka Ho ditolak berarti biaya promosi $\left(\mathrm{X}_{1}\right)$ berpengaruh secara signifikan terhadap laba $(\mathrm{Y})$. Berarti dapat dikatakan bahwa biaya promosi secara individu berpengaruh terhadap peningkatan laba.

Dari perhitungan tersebut diperoleh hasil dari thitung untuk Biaya Umum $\left(\mathrm{X}_{2}\right)$ sebesar 3,874 dan $t_{\text {tabel }}$ sebesar 3,18, berarti $t_{\text {hitung }}>t_{\text {tabel }}$ maka Ho ditolak berarti Biaya Umum $\left(\mathrm{X}_{2}\right)$ berpengaruh secara signifikan terhadap laba (Y). Berarti dapat dikatakan bahwa Biaya Umum secara individu berpengaruh terhadap peningkatan laba.

Dari perhitungan tersebut diperoleh hasil dari thitung untuk Biaya Umum $\left(\mathrm{X}_{3}\right)$ sebesar 4,223 dan $t_{\text {tabel }}$ sebesar 3,18, berarti $t_{\text {hitung }}>t_{\text {tabel }}$ maka Ho ditolak berarti volume penjualan $\left(\mathrm{X}_{3}\right)$ berpengaruh secara signifikan terhadap laba $(\mathrm{Y})$. Berarti dapat dikatakan bahwa volume penjualan secara individu berpengaruh terhadap peningkatan laba.

d. Uji F

Dari hasil perhitungan tersebut diperoleh $F_{\text {hit }}$ sebesar 9289,989. Ternyata besarnya $\mathrm{F}_{\text {reg }}$ terletak di daerah penolakan Ho, yaitu $\mathrm{F}_{\text {hit }}$ lebih besar dari $\mathrm{F}_{\text {tabel }}$ atau 9289,989> 215,71. Sehingga secara bersama-sama ada pengaruh yang signifikan biaya promosi $\left(\mathrm{X}_{1}\right)$, biaya umum $\left(\mathrm{X}_{2}\right)$, volume penjualan $\left(\mathrm{X}_{3}\right)$ dan biaya terhadap laba.

Dari hasil perhitungan antara keempat variabel yang diamati, yaitu menguji pengaruh antara variabel independent (bebas) yaitu biaya promosi, biaya umum dan volume penjualan secara bersama-sama terhadap variabel dependen (terikat) yaitu laba. Dapat diperoleh bahwa biaya promosi mempunyai pengaruh yang paling dominan terhadap laba dengan hasil perhitungan sebesar 49,760,

e. Koefisien Determinasi $\left(\mathrm{R}^{2}\right)$

Koefisien determinasi ini digunakan untuk mengetahui berapa besar variasi $\mathrm{Y}$ yang dapat dijelaskan oleh variasi $\mathrm{X}$, yaitu untuk mengetahui seberapa besar pengaruh biaya promosi, biaya umum dan volume penjualan terhadap laba secara bersama-sama. Berdasarkan hasil perhitungan komputer program SPSS versi 12.00 diperoleh $\mathrm{R}^{2}=0,999$, ini dapat diartikan bahwa 99,9\% perubahan/variasi Y (laba) dikarenakan oleh adanya perubahan/variasi variabel $\mathrm{X}$ (biaya promosi, biaya umum dan volume penjualan) sedangkan $0,1 \%$ sisanya dikarenakan oleh adanya perubahan variabel lain yang tidak masuk dalam model misalnya biaya distribusi, harga dan pelayanan.

\section{KESIMPULAN}

Dari hasil penelitian, analisis data, dan pembahasan pada bab-bab sebelumnya, maka dapat diambil kesimpulan sebagai berikut:

1. Berdasarkan hasil uji t tentang variabel biaya promosi didapatkan bahwa secara individu biaya promosi mempunyai pengaruh terhadap laba.

2. Berdasarkan hasil uji t tentang variabel biaya umum bahwa secara individu biaya umum mempunyai pengaruh terhadap laba. 
3. Berdasarkan hasil uji t tentang variabel volume penjualan bahwa secara individu volume penjualan mempunyai pengaruh terhadap laba.

4. Berdasarkan hasil uji $\mathrm{F}$ didapatkan bahwa secara bersama-sama biaya promosi, biaya umum dan volume penjualan berpengaruh terhadap laba.

5. Berdasarkan hasil analisis data dengan menggunakan bantuan komputer program SPSS versi 11.00, maka dapat diperoleh $R$ Square $\left(R^{2}\right)$ sebesar $R^{2}=0,999$, ini dapat diartikan bahwa 99,9\% perubahan/variasi Y (laba) dikarenakan oleh adanya perubahan/variasi variabel $\mathrm{X}$ (biaya promosi, biaya umum dan volume penjualan) sedangkan $0,1 \%$ sisanya dikarenakan oleh adanya perubahan variabel lain yang tidak masuk dalam model misalnya biaya distribusi, harga dan pelayanan.

\section{SARAN}

Dari hasil penelitian, analisis data, pembahasan dan kesimpulan yang telah diambil, maka dapat dikemukakan saran sebagai berikut:

1. Mengingat bahwa biaya promosi mempunyai pengaruh yang kuat dengan peningkatan laba, hendaknya digunakan sarana media iklan yang tepat dan efektif, sehingga biaya yang dikeluarkan tidak sia-sia.

2. Upaya peningkatan laba sebaiknya perusahaan menerapkan strategi pemasaran dengan cara menetapkan harga jual yang tepat yaitu harga dapat dijangkau oleh semua konsumen baik golongan atas sampai bawah.

3. Sebaiknya perusahaan dalam meningkatkan laba dengan cara memberikan potongan harga atau discount kepada konsumen yang membeli produk dengan volume yang ditentukan perusahaan.

4. Sebaiknya perusahaan melakukan promosi secara kontinyu sehingga konsumen mengakui bahwa produk yang dihasilkan benar-benar ada.

\section{DAFTAR PUSTAKA}

Abdul Halim, M.B.A., Akuntan. 1999. Dasar-dasar akuntansi Biaya. Yogyakarta: BPFE UGM.

Arikunto, Suharsimi. 2006. Prosedur Penelitian Suatu Pendekatan Praktek. Jakarta: Rineka Cipt

Arsyad, Lincoln. 1994. Ekonomi Manajerial, Yogyakarta: BPFE.

Djarwanto, PS dan Subagyo Pangestu. 1998. Statistik Induktif, Yogya: BPFE.

Keraf, Gorys. 2001. Komposisi Sebuah Pengantar Kemahiran Bahasa. Nusa Indah: Ende Flores.

Mulyadi. 1993. Akuntansi Biaya. Edisi 6. Yogyakarta: BPFE.

Soeratno dan Lincolyn Arsyad. 1993. Metode Penelitian untuk Ekonomi dan Bisnis. Yogyakarta: Lembaga Penerbit AMP YKPN.

Supriyono. 1999. Akuntansi Manajemen Konsep Dasar Akuntansi Manajemen dan Pusat Perencanaan Edisi Enam. Yogyakarta: BPFE. 
Swastha Basu dan Irawan. 1990. Manajemen Pemasaran Modern. Jogjakarta: Liberty.

\section{PERAGA DAN TABEL}

Tabel 1

Hasil Pengujian Normalitas Masing-masing Variabel

\begin{tabular}{|c|l|c|c|c|}
\hline No & \multicolumn{1}{|c|}{ Variabel } & $\begin{array}{c}\text { Asymp Sign } \\
(2 \text {-tailed } \mathrm{P})\end{array}$ & Keterangan & Distribusi \\
\hline 1 & Biaya promosi & 0,991 & $\mathrm{P}>0,05$ & Normal \\
\hline 2 & Biaya umum & 0,953 & $\mathrm{P}>0,05$ & Normal \\
\hline 3 & Volume penjualan & 0,973 & $\mathrm{P}>0,05$ & Normal \\
\hline 5 & Laba & 0,800 & $\mathrm{P}>0,05$ & Normal \\
\hline
\end{tabular}

Sumber: Data sekunder yang diolah

Tabel 2

Rekapitulasi Regresi Parsial dan Uji t

\begin{tabular}{|c|c|c|c|c|c|}
\hline Variabel & Constant & Coef. Reg. & $\begin{array}{l}\text { Std. } \\
\text { Error }\end{array}$ & $t_{\text {hit }}$ & Sig \\
\hline Biaya promosi & 40955295 & 32,959 & 4,016 & 8,207 & 0,004 \\
\hline Biaya umum & 54294134 & 58,234 & 15,031 & 3,874 & 0,030 \\
\hline Volume penjualan & 338078891,2572 & 0,898 & 0,213 & 4,223 & 0,024 \\
\hline
\end{tabular}

Sumber: Data sekunder yang diolah

Tabel 3

Uji Normalitas

One-Sample Kolmogorov-Smirnov Test

\begin{tabular}{|ll|r|r|r|r|}
\hline & & \multicolumn{1}{|c|}{$\begin{array}{c}\text { Biaya } \\
\text { Promosi }\end{array}$} & Biaya Umum & \multicolumn{2}{c|}{$\begin{array}{c}\text { Volume } \\
\text { Penjualan }\end{array}$} \\
\hline N & & 5 & 5 & \multicolumn{1}{c|}{ Laba } \\
Normal Parameters a,b & Mean & 4637380 & 2395620,00 & $5.92 \mathrm{E}+08$ & $1.9 \mathrm{E}+08$ \\
& Std. Deviation & 434986.1 & 229706,437 & 15098302 & $1.5 \mathrm{E}+07$ \\
Most Extreme & Absolute &, 195 &, 231 &, 217 &, 288 \\
Diff erences & Positive &, 188 &, 173 &, 207 &, 227 \\
& Negative &,- 195 &,- 231 &,- 217 &,- 288 \\
Kolmogorov -Smirnov Z & &, 436 &, 516 &, 485 &, 645 \\
Asy mp. Sig. (2-tailed) & &, 991 &, 953 &, 973 &, 800 \\
\hline
\end{tabular}

a. Test distribution is Normal.

b. Calculated from data. 
Tabel 4

Uji Linieritas

Model Summary

\begin{tabular}{|l|r|r|r|r|r|}
\hline Model & $\mathrm{R}$ & $\mathrm{R}$ Square & $\begin{array}{c}\text { Adjusted } \\
\text { R Square }\end{array}$ & $\begin{array}{c}\text { Std. Error of } \\
\text { the Estimate }\end{array}$ & $\begin{array}{c}\text { Durbin- } \\
\text { Wat son }\end{array}$ \\
\hline 1 &, $999^{\mathrm{a}}$ &, 999 &, 999 & 175537,539 & 2,799 \\
\hline
\end{tabular}

a. Predictors: (Constant), Volume Penjualan, Biay a Umum, Biay a Promosi

b. Dependent Variable: Laba

Tabel 5

Analisis Regresi Parsial Antara Biaya Promosi Terhadap Laba

Variables Entered/RemovedP

\begin{tabular}{|l|l|l|l|}
\hline Model & Variables Entered & Variables & Removed \\
\hline 1 & Biaya Promos & Method \\
\hline
\end{tabular}

a. All requested $v$ ariables entered.

b. Dependent Variable: Laba

Model Summaryb

\begin{tabular}{|l|r|r|r|r|r|}
\hline Model & R & R Square & $\begin{array}{c}\text { Adjusted } \\
\text { R Square }\end{array}$ & $\begin{array}{c}\text { Std. Error of } \\
\text { the Estimate }\end{array}$ & $\begin{array}{c}\text { Durbin- } \\
\text { Wat son }\end{array}$ \\
\hline 1 &, $978^{\mathrm{a}}$ &, 957 &, 943 & 3493877,286 & 2,632 \\
\hline
\end{tabular}

a. Predictors: (Constant), Biay a Promosi

b. Dependent Variable: Laba

ANOV A

\begin{tabular}{|c|c|c|c|c|c|c|}
\hline Model & & $\begin{array}{l}\text { Sum of } \\
\text { Squares }\end{array}$ & df & Mean Square & $\mathrm{F}$ & Sig. \\
\hline \multirow[t]{3}{*}{1} & Regression & $8.22 \mathrm{E}+14$ & 1 & $8.222 \mathrm{E}+14$ & 67,352 &, $004^{a}$ \\
\hline & Residual & $3.66 E+13$ & 3 & $1.221 \mathrm{E}+13$ & & \\
\hline & Total & $8.59 E+14$ & 4 & & & \\
\hline
\end{tabular}

a. Predictors: (Const ant), Biay a Promosi

b. Dependent Variable: Laba

\section{Coefficients}

\begin{tabular}{|c|c|c|c|c|c|c|}
\hline \multirow{2}{*}{\multicolumn{2}{|c|}{ Model }} & \multicolumn{2}{|c|}{$\begin{array}{l}\text { Unstandardized } \\
\text { Coeff icients }\end{array}$} & \multirow{2}{*}{$\begin{array}{c}\text { Standardized } \\
\text { Coeff icients } \\
\text { Beta }\end{array}$} & \multirow[b]{2}{*}{$\mathrm{t}$} & \multirow[b]{2}{*}{ Sig. } \\
\hline & & B & Std. Error & & & \\
\hline \multirow[t]{2}{*}{1} & (Constant) & $4.1 \mathrm{E}+07$ & $1.9 \mathrm{E}+07$ & & 2,191 &, 116 \\
\hline & Biay a Promosi & 32,959 & 4,016 & ,978 & 8,207 & ,004 \\
\hline
\end{tabular}

a. Dependent Variable: Laba 
Residuals Statisti cs ${ }^{a}$

\begin{tabular}{|l|r|r|r|r|r|}
\hline & Minimum & Maximum & \multicolumn{1}{c|}{ Mean } & Std. Dev iation & $\mathrm{N}$ \\
\hline Predicted Value & $1.8 \mathrm{E}+08$ & $2.1 \mathrm{E}+08$ & $1.9 \mathrm{E}+08$ & 14336827,269 & 5 \\
Residual & -2350605 & 5136090 &, 000 & 3025786,488 & 5 \\
Std. Predicted Value & $-1,235$ & 1,066 & , O00 & 1,000 & 5 \\
Std. Residual &,- 673 & 1,470 &, 000 &, 866 & 5 \\
\hline
\end{tabular}

a. Dependent Variable: Laba

Tabel 6

Analisis Regresi Parsial Antara Biaya Umum Terhadap Laba

Variables Entered/RemovedP

\begin{tabular}{|c|c|c|c|}
\hline Model & Variables Entered & $\begin{array}{l}\text { Variables } \\
\text { Removed }\end{array}$ & Method \\
\hline 1 & Biaya Umuma & - & Enter \\
\hline
\end{tabular}

a. All requested $v$ ariables entered.

b. Dependent Variable: Laba

\begin{tabular}{|l|r|r|r|r|c|}
\multicolumn{9}{c|}{ Model Summary } \\
\hline & $\mathrm{R}$ & $\mathrm{R}$ Square & $\begin{array}{c}\text { Adjusted } \\
\mathrm{R} \text { Square }\end{array}$ & $\begin{array}{c}\text { Std. Error of } \\
\text { the Estimate }\end{array}$ & $\begin{array}{c}\text { Durbin- } \\
\text { Wat Son }\end{array}$ \\
\hline 1 &, $913^{\mathrm{a}}$ &, 833 &, 778 & 6905549,054 & 2,691 \\
\hline
\end{tabular}

a. Predictors: (Constant), Biay a Umum

b. Dependent Variable: Laba

ANOV A

\begin{tabular}{|c|c|c|c|c|c|c|}
\hline Model & & $\begin{array}{l}\text { Sum of } \\
\text { Squares }\end{array}$ & df & Mean Square & $\mathrm{F}$ & Sig. \\
\hline 1 & $\begin{array}{l}\text { Regression } \\
\text { Residual } \\
\text { Total }\end{array}$ & $\begin{array}{l}7.16 E+14 \\
1.43 E+14 \\
8.59 E+14\end{array}$ & $\begin{array}{l}1 \\
3 \\
4\end{array}$ & $\begin{array}{l}7.157 E+14 \\
4.769 E+13\end{array}$ & 15,009 &, $030^{a}$ \\
\hline
\end{tabular}

a. Predictors: (Constant), Biay a Umum

b. Dependent Variable: Laba

Coeffi cients ${ }^{\mathrm{a}}$

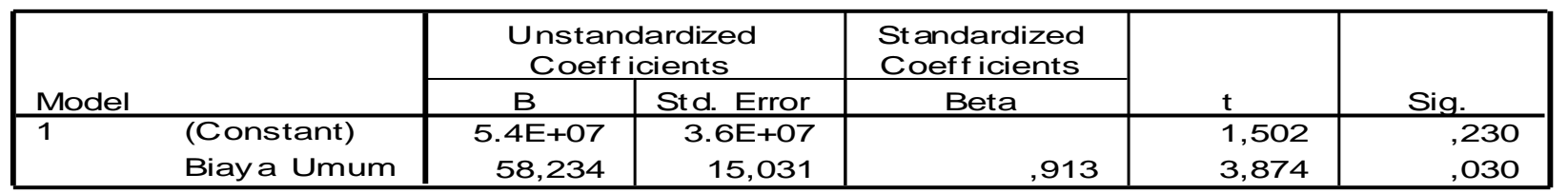

a. Dependent Variable: Laba

Residuals Statisti cs

\begin{tabular}{|l|r|r|r|r|r|}
\hline & Minimum & Maximum & \multicolumn{1}{|c|}{ Mean } & Std. Dev iat ion & $\mathrm{N}$ \\
\hline Predicted Value & $1.7 \mathrm{E}+08$ & $2.1 \mathrm{E}+08$ & $1.9 \mathrm{E}+08$ & 13376660,428 & 5 \\
Residual & $-1.0 \mathrm{E}+07$ & 3753465 &, 000 & 5980380,908 & 5 \\
Std. Predicted Value & $-1,611$ &, 944 &, 000 & 1,000 & 5 \\
Std. Residual & $-1,516$ &, 544 &, 000 &, 866 & 5 \\
\hline
\end{tabular}

a. Dependent Variable: Laba 
Tabel 7

Analisis Regresi Parsial Antara Volume Penjualan Terhadap Laba

Variables Entered/Removedp

\begin{tabular}{|l|c|c|c|}
\hline Model & Variables Entered & $\begin{array}{c}\text { Variables } \\
\text { Removed }\end{array}$ & Method \\
\hline 1 & Volume Penjualan & & \\
\hline
\end{tabular}

a. All requested $V$ ariables entered.

b. Dependent Variable: Laba

\begin{tabular}{|c|c|c|c|c|c|}
\hline \multicolumn{6}{|c|}{ Model Summaryb } \\
\hline Model & $\mathbf{R}$ & R Square & $\begin{array}{l}\text { Adjusted } \\
\text { R Square }\end{array}$ & $\begin{array}{l}\text { Std. Error of } \\
\text { the Estimate }\end{array}$ & $\begin{array}{l}\text { Durbin- } \\
\text { Watson }\end{array}$ \\
\hline 1 &, $925^{a}$ &, 856 &, 808 & 6420400,105 & 2,127 \\
\hline
\end{tabular}

a. Predictors: (Constant), Volume Penjualan

b. Dependent Variable: Laba

ANOVAb

\begin{tabular}{|c|c|c|c|c|c|c|}
\hline \multicolumn{2}{|c|}{ Model } & $\begin{array}{l}\text { Sum of } \\
\text { Squares }\end{array}$ & df & Mean Square & $\mathrm{F}$ & Sig. \\
\hline \multirow[t]{3}{*}{1} & Regression & $7.35 \mathrm{E}+14$ & 1 & $7.351 \mathrm{E}+14$ & 17,834 &, $024^{a}$ \\
\hline & Residual & $1.24 E+14$ & 3 & $4.122 \mathrm{E}+13$ & & \\
\hline & Total & $8.59 E+14$ & 4 & & & \\
\hline
\end{tabular}

a. Predictors: (Constant), Volume Penjualan

b. Dependent Variable: Laba

Coefficients ${ }^{\mathrm{a}}$

\begin{tabular}{|c|c|c|c|c|c|c|}
\hline \multirow{2}{*}{\multicolumn{2}{|c|}{ Model }} & \multicolumn{2}{|c|}{ Unstandardized Coeff icients } & \multirow{2}{*}{$\begin{array}{c}\text { St andardized } \\
\text { Coeff icients } \\
\text { Beta }\end{array}$} & \multirow[b]{2}{*}{$\mathrm{t}$} & \multirow[b]{2}{*}{ Sig. } \\
\hline & & $\mathrm{B}$ & Std. Error & & & \\
\hline \multirow[t]{2}{*}{1} & (Constant) & 338078891,257 & 125980698.07 & & 2,684 &, 075 \\
\hline & Volume Penjualan & ,898 & ,213 & ,925 & 4,223 & ,024 \\
\hline
\end{tabular}

a. Dependent Variable: Laba

Tabel 8

Analisis Regresi Linier Berganda

Variables Entered/RemovedP

\begin{tabular}{|l|l|l|l|}
\hline Model & \multicolumn{1}{|c|}{ Variables Entered } & $\begin{array}{c}\text { Variables } \\
\text { Removed }\end{array}$ & Method \\
\hline 1 & $\begin{array}{l}\text { Volume Penjualan, Biay a } \\
\text { Umum, Biay a Promosi }\end{array}$ & & Enter \\
\hline
\end{tabular}

a. All requested $v$ ariables entered.

b. Dependent Variable: Laba 
Model Summary

\begin{tabular}{|l|r|r|r|r|}
\hline Model & $R$ & $R$ Square & $\begin{array}{c}\text { Adjusted } \\
\text { R Square }\end{array}$ & $\begin{array}{c}\text { St d. Error Of } \\
\text { the Estimate }\end{array}$ \\
\hline 1 &, $999^{a}$ &, 999 &, 999 & 175537,539 \\
\hline
\end{tabular}

a. Predictors: (Constant), Volume Penjualan, Biay a Umum, Biay a Promosi

ANOVA ${ }^{\mathbf{b}}$

\begin{tabular}{|c|c|c|c|c|c|c|}
\hline Model & & $\begin{array}{l}\text { Sum of } \\
\text { Squares }\end{array}$ & df & Mean Square & $\mathrm{F}$ & Sig. \\
\hline 1 & $\begin{array}{l}\text { Regression } \\
\text { Residual } \\
\text { Total }\end{array}$ & $\begin{array}{l}8.59 E+14 \\
3.08 E+10 \\
8.59 E+14\end{array}$ & $\begin{array}{l}3 \\
1 \\
4\end{array}$ & $\begin{array}{l}2.863 E+14 \\
3.081 E+10\end{array}$ & 9289,989 &, $008^{2}$ \\
\hline
\end{tabular}

a. Predictors: (Const ant), Volume Penjualan, Biay a Umum, Biay a Promosi

b. Dependent Variable: Laba

\begin{tabular}{|c|c|c|c|c|c|c|}
\hline \multicolumn{7}{|c|}{ Coefficients $^{a}$} \\
\hline \multirow{2}{*}{\multicolumn{2}{|c|}{ Model }} & \multicolumn{2}{|c|}{ Unstandardized Coeff icients } & \multirow{2}{*}{$\begin{array}{c}\text { Standardized } \\
\text { Coeff icients } \\
\text { Beta }\end{array}$} & \multirow[b]{2}{*}{$\mathrm{t}$} & \multirow[b]{2}{*}{ Sig. } \\
\hline & & $\mathrm{B}$ & Std. Error & & & \\
\hline \multirow[t]{4}{*}{1} & (Constant) & 635267745.50 & 17281988.1 & & 36,759 &, 017 \\
\hline & Biay a Promosi & 96,551 & 1,940 & 2,866 & 49,760 &, 013 \\
\hline & Biaya Umum & 35,714 & 1,493 &, 560 & 23,920 & ,027 \\
\hline & Volume Penjualan & 1,357 & ,039 & 1,398 & 34,447 & ,018 \\
\hline
\end{tabular}

a. Dependent Variable: Laba

Tabel 9

Descriptives

\section{Descriptive Statistics}

\begin{tabular}{|l|r|r|r|r|r|}
\hline & N & Minimum & Maximum & \multicolumn{1}{|c|}{ Mean } & Std. Dev iation \\
\hline Biaya Promosi & 5 & 4100000 & 5101000 & 4637380,00 & 434986,060 \\
Biaya Umum & 5 & 2025500 & 2612400 & 2395620,00 & 229706,437 \\
Volume Penjualan & 5 & 577000000 & 610000000 & 592362000 & 15098301,891 \\
Laba & 5 & 176000000 & 207000000 & 193800000 & 14652644,812 \\
Valid N (listwise) & 5 & & & & \\
\hline
\end{tabular}

Influence Analysis Expense Of Promotion, General Expense And Volume Of Trading To Profit At Samidi Glass \& Craft Gondang, Balance, Sukoharjo (Jumingan, Sarwanti) 